\title{
POST-HERETIC NEURALGIA; INTRA-LESIONAL TRIAMCINOLONE IN THE TREATMENT
}

1. FCPS (derma), Diplomate Derma (RCPSG)

Assistant Prof Dermatology DIMC, DUHS

2. FCPS

Assistant Prof Dermatology Hamdard College of medicine and dentistry

3. FCPS

Assistant Prof Neurology

DIMC, DUHS

4. MCPS, FCPS, FRCP

Professor of Medicine

DIMC, DUHS

Correspondence Address:

Dr. Sadaf Ahmed Asim

FCPS (derma), Diplomate Derma (RCPSG)

Assistant Prof Dermatology

DIMC, DUHS

doc.sadaf.ahmed@gmail.com

Article received on:

05/11/2015

Accepted for publication:

03/12/2015

Received after proof reading:

$13 / 01 / 2016$
Dr. Sadaf Ahmed Asim¹, Dr. Humaira Maryum Agha ${ }^{2}$, Dr. Qamar-un-Nisa ${ }^{3}$, Prof. Muhammad Masroor ${ }^{4}$

ABSTRACT... Objectives: To assess the efficacy of intra-lesional triamcinolone in for the treatment of Post Herpetic Neuralgia. Study Design: Prospective interventional study. Setting: Dermatology Department of Dow University Hospital. Period: July 2014 to June 2015. Patients and Methods: Twenty nine patients with diagnosis of Post Herpetic Neuralgia were included after taking written and informed consent. An insulin syringe was used for the injections and the medicines were injected intralesionally. The mixture contained $30 / 70 \%$ of triamcinolone to xylocaine ratio for local infiltration in post herpetic scars. Pain relief assessment was done with the help of visual analogue scale (VAS) after two months. Mean pain score before therapy and after therapy was compared with one sample student t test. Results: Out of total 29 patients 14 were male and 15 were females. The mean age \pm SD was found to be $45.9 \pm 15.4$ years. The most common region involved was Chest. The mean \pm SD duration of Symptoms was $5.58 \pm$ 1.80 weeks. The mean pain score before therapy was $6.86 \pm 1.66$ which after one month of therapy reduced to $3.72 \pm 1.86$. The reduction in pain was statistically significant $(p<0.001)$. Conclusion: Post Herpetic Neuralgia can be effectively treated by the local infiltration of a mixture of triamcinolone and lignocaine. It is recommended that long-term follow-up studies should be done with corticosteroids only or in combination with local anesthetics to additionally evaluate the effectiveness of such treatment in postherpetic neuralgia.

Key words: $\quad$ Postherpetic neuralgia, triamcinolone, lignocaine, pain

Article Citation: Asim SA, Agha HM, Qamar-un-Nisa, Masroor M. Post-heretic neuralgia; intralesional triamcinolone in the treatment. Professional Med J 2016;23(1):056059. DOI: 10.17957/TPMJ/16.3155

\section{INTRODUCTION}

Post herpetic neuralgia (PHN) is actually pain remained at the dermatomes which is involved in herpes zoster attack later than the active infection. ${ }^{1,2}$ Post herpetic neuralgia needs early and effective treatment because of its distressing character. Its worldwide infection rate is $9-14 \%$ which is however more variable according to age. Post Herpetic Neuralgia is seen to be more common in old age i.e. more than $60 \% .^{3}$ Half of these patients usually feel pain up to 3 months while in some patients it persists for even 1 year after the onset.

Even though some clinical studies have been done on the treatment of Herpes Zoster, but still there is a debate that which treatment is the best." Particularly to manage the post Herpetic neuralgia this indecision exists yet. ${ }^{4,5}$ Different medical and surgical strategies tried over the years including antiviral drugs, pain relievers, Percutaneous nerve stimulants, antidepressants, anti-seizure and topical agents etc. are being used but unfortunately the effect is usually incomplete or transitory and the therapeutic efficacy of many of them is elusive because the disease is very unpredictable. ${ }^{6,7}$

One drug which has given a little better results in previous years which is Corticosteroid can be used at the diseased site by local infiltration either only or in combination with local anesthetics. Its effect is by anti-inflammatory action. It is said that if this drug is infiltrated in the healed lesions of Herpes Zoster at the initial stages then the chances of Post Herpetic Neuralgia is even decreased. ${ }^{8}$ The fact for the value of corticosteroid therapy is strong, while published studies which discourage its use is weak. ${ }^{9}$ 
Taking into consideration the deficiency in the consensus existing in this vicinity, this study was being planned to see effectiveness of Intralesional Trimacolone in the treatment of Post herptic Neuralgia. This will help in answering that which treatment is best for Post Herpetic neuralgia by decreasing pain and improving the quality of life..$^{10}$

\section{PATIENTS AND METHODS}

This prospective interventional study was done in Dermatology Department of Dow University Hospital from July 2014 to June 2015. Twenty nine patients of age between 16-60 years with a clinical diagnosis of Post Herpetic Neuralgia were included after taking written and informed consent.

Those patients who had persistent pain after one month of the onset of herpes zoster were included in the study. A detailed history, a thorough clinical examination was done to diagnose the disease. Those patients who had any history of diabetes, hypertension, glaucoma, or a known hypersensitivity to lignocaine, recent intake of systemicsteroids, antidepressantsorantipsychotic drugs were excluded. The dermatome which was involved was selected, and the area of scar was marked. An insulin syringe was used for the injections and the medicines were injected intralesionally. The mixture contained $30 / 70 \%$ of triamcinolone to xylocaine ratio for local infiltration in post herpetic scars. Patients were first followed 14 days after first therapy and second infiltration done if required. Pain relief assessment was done after 2 months. This was done with the help of visual analogue scale (VAS) ${ }^{6}$ where the patient was asked to grade his pain by marking any point on a $10 \mathrm{~cm}$ straight line marked from $0-10$. Zero was no pain whereas 10 was extreme unbearable pain hampering the daily routine work or sleep.

Mean pain score before therapy and after therapy was compared with one sample student test. Level of significant was $p<0.05$.

\section{RESULTS}

Out of total 29 patients 14 were male and 15 were females. The mean age $\pm S D$ was found to be $45.9 \pm 15.4$ years. The most common region involved was Chest. The mean $\pm S D$ duration of Symptoms was $5.58 \pm 1.80$ weeks.All demographic details shown in Table-l.

Twenty patients (69\%) required a second infiltration of therapy as pain was more than 5 on VAS after 14 days of first therapy. The mean pain score before therapy was $6.86 \pm 1.66$ which after one month of therapy reduced to $3.72 \pm 1.86$. The reduction in pain was statistically significant $(p<0.001)$. [Shown in Table-II]

There was no complication reported in all patients as only small gauge needle used and minimum amount of local anesthesia was used for the procedure.

\begin{tabular}{|c|c|c|c|c|}
\hline \multicolumn{2}{|c|}{ Variable } & \multicolumn{3}{|c|}{ Value } \\
\hline \multicolumn{2}{|c|}{ Age (years) } & \multicolumn{3}{|c|}{$45.9 \pm 15.4$} \\
\hline $\begin{array}{ll}\text { Gender } & \\
& \text { Male } \\
& \text { Fem }\end{array}$ & $\begin{array}{l}\text { Male } \\
\text { Female }\end{array}$ & \multicolumn{3}{|c|}{$\begin{array}{l}14(48.3) \\
15\end{array}$} \\
\hline \multicolumn{2}{|c|}{$\begin{array}{ll}\text { Region } & \\
& \text { Chest } \\
& \text { Thigh } \\
& \text { Face } \\
\text { Neck } \\
\text { Abdomen } \\
\text { Hip } \\
\text { Arm } \\
\text { Groin }\end{array}$} & & 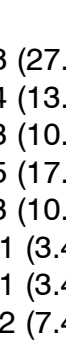 & \\
\hline \multicolumn{2}{|c|}{$\begin{array}{l}\text { Duration of Post herpetic } \\
\text { Neurolangia (weeks) }\end{array}$} & \multicolumn{3}{|c|}{$5.58 \pm 1.80$} \\
\hline \multicolumn{2}{|c|}{ Daily activities problem } & \multicolumn{3}{|c|}{$25(86.2)$} \\
\hline \multicolumn{5}{|c|}{$\begin{array}{l}\text { Table-I. Demographic profile of the subjects with post } \\
\text { herpetic neuralgia }(n=29)\end{array}$} \\
\hline $\begin{array}{l}\text { Pre therapy } \\
\text { pain }\end{array}$ & $\begin{array}{l}\text { Post therapy } \\
\text { pain }\end{array}$ & t value & Df & $P$ value \\
\hline $6.86 \pm 1.66$ & $3.72 \pm 1.86$ & 12.00 & 28 & $<0.001$ \\
\hline \multicolumn{5}{|c|}{ Table-II. Mean pain before and after therapy $(n=29)$} \\
\hline
\end{tabular}

\section{DISCUSSION}

The decrease in mean pain score i.e. from 6.86 to 3.72 after the therapy proofs that the treatment of Post Herpetic neuralgia is very helpful and valuable by intralesional triamcinolne. 
Some studies including Eaglstein and his team also said in their study that corticosteroids eases the pain and reduces the chances of constant pain. ${ }^{11,12,13}$ The intralesional treatment given to patients in this study also did the equivalent but in a higher amount of patients.

Researchers have shown that there is not any single proven treatment of PHN which is constantly effective, however different treatment methods have been found to decrease the extent and severity of the disease successfully including different antiviral drugs, pain killer, antidepressants9, anti-seizures, capsaicin, some topical oil, nerve block, transcutaneous nerve stimulants and intra thecal drugs administration. Besides that some studies have been done on local anesthetics given either by topically or infiltrated locally at the site of lesion, nerve or epidural space with temporary effect. ${ }^{14,15,16}$

It has been considered that this treatment with corticosteroids can cause spread of viral infection again but there is no proven evidence reported yet. ${ }^{17}$ Besides that resistance of the drug has been reported so clinicians should use the accurate dosage. ${ }^{18}$

There is some data that the local anesthetic is not the essential element in this combination therapy which said in their study that the treatment result was also found to be good in one patient in which normal saline was used instead of the local anesthetic. They used both triamcinolone and procaine separately but didn't get any advantage. Procaine alone was also unsuccessful in three cases stated by Sehgal and Gardner. ${ }^{19}$ Apart from the discussion that either the useful results are found in the patients who got corticosteroid or the local anesthetic or the combination, but it is of practical significance that the combination of both are successful in the patients of post herpeticneuralgia. It should be noted that in majority of patients repetitions of the injections may be required because only in few cases decreases in pain occurs after the first injection.

This study however did not say anything about the effect of drug on the duration and course of the disease as compare to the other studies in which duration of study was addressed. ${ }^{6}$ so its necessary to do studies with active follow up of the patients. Besides that there was no control group present and also the complications of the treatment method were also not observed.

\section{CONCLUSION}

Post Herpetic Neuralgia can be effectively treated by the local infiltration of a mixture of triamcinolone and lignocaine. It is recommended that long-term follow-up studies should be done with corticosteroids only or in combination with local anesthetics to additionally evaluate the effectiveness of such treatment in post herpetic neuralgia.

Copyright $@ 03$ Dec, 2015.

\section{REFERENCES}

1. Watson CPN. Postherpcticneuralgia. NeurolClin. 1989; 7: 231-248.

2. Price RW. Herpes zoster. An approach to systemic therapy. MedClin North Am. 1982; 66: 1105-1118.

3. Ragozzino MW, Melton J, Kurland LT, Chu CP, Perry $\mathrm{HO}$. Population-based study of herpes zoster and its sequelae. Medicine. 1982; 61: 310-316.

4. Jolleys JV. Treatment of shingles and post-herpetic neuralgia. BMJ.1989; 298: 1537-1538.

5. Anonynmous. Acyclovir in general practice [editorial]. Drug Ther Bull .1992; 26: 101-103.

6. Watson CPN, Evans RJ. Postherpetic neuralgia: a review. Arch Neurol. 1986; 43: 836-840.

7. Kost RG, Straus SE. Postherpetic neuralgia, pathogenesis, treatment and prevention. $\mathrm{N}$ Engl $\mathrm{J}$ Med .1999; 338: 32-42.

8. Sterling JC, Kurtz JB. Viral infection. In: Champion $\mathrm{RH}$, Burton JL, Burn DA, Breathnach SM, (edi). Textbook of dermatology. Oxford: Blackwell Science. 1998; 101821.

9. Dickinson JA. Should we treat herpes zoster with corticosteroid agents? Med J Aust. 1986;144(7):375, 378-80.

10. Jimmy Volmink, Tim Lancaster, Stephen Gray, and Chris Silagy. Treatments for postherpetic neuralgia-a systematic review of randomized controlled trials. 
Family Practice. 1996;13 (1): 84-91.

11. Eaglstein WH, Katz R, Brown JA. The effects of early corticosteroid therapy on the skin eruption and pain of herpes zoster. JAMA.1970;211:1681.

12. Bhargava R, Bhargava S, Haldia KN, Bhargava P. Jaipur block in postherpetic neuralgia. Int J Dermatol.1998; 37: 465-8. 17.

13. Khalid M, Ghulam MG. Treatment of postherpetic neuralgia with subcutaneous injection of a mixture of xylocaine, bupivacaine and dexamethasone. J Pak AssocDermatol.1999; 9: 12-15.

14. Johnson RW, Whitton TL. Management of herpes zoster (shingles) and postherpeticneuralgia. Expert OpinPharmacother.2004; 5: 551-9.

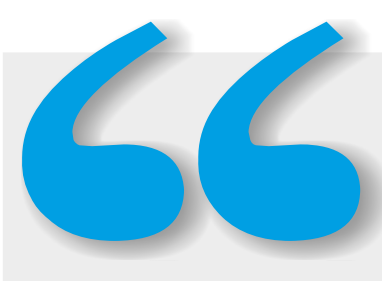

15. Johnson R. Herpes Zoster. Predicting and minimizing the impact of postherpetic neuralgia. $J$ AntimicrobChemother.2001; 47: 1- 8.

16. Hashizume K. Herpes zoster and postherpeticneuralgia. Nippon Rhinsho.2001; 59: 1738-42.

17. Epstein E. Triamcinolone-Procaine in the Treatment of Zoster and Postzoster Neuralgia. Calif Med. 1971; 115(2): 6-10.

18. Christopher L,Stephen S. Primary care management of acute herpes zoster: systematic review of evidence from randomized controlled trials. $\mathrm{Br} \mathrm{J}$ Gen Pract.1995, 45, 39-45.

19. Sehgal D, Gardner WJ. Postherpetic neuralgia. Neurology.1962;12:725.

\section{"Innovation distinguishes between a leader and a follower."}

\section{AUTHORSHIP AND CONTRIBUTION DECLARATION}

\begin{tabular}{|c|r|}
\hline Sr. \# & Author-s Full Name \\
1 & Dr. Sadaf Ahmed Asim \\
\hline
\end{tabular}

2

Dr. Humaira Maryum Agha

3

Dr. Qamar-un-Nisa

4 Prof. Muhammad Masroor
Contribution to the paper

Conception \& design,

Collection \& Analysis of data, Drafting of article Final approval of article Analysis \& interpetation of data, Collection \& Assembly of data, Analysis \& interpretation of data Statistical expertise

Drafting of article, Critical revision of article of important intellectual content
Author $=\mathbf{s}$ Signature
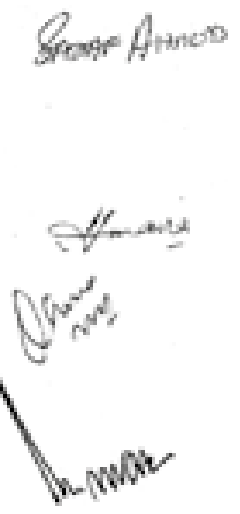